\title{
Exploring the effects of firm and product characteristics on cost system's features
}

\author{
Evdokia I. Tsifora ${ }^{1}$, Prodromos D. Chatzoglou ${ }^{2}$
}

\begin{abstract}
:
The present study examines the associations between the various factors which are related to the process of assigning the production cost (direct and mainly indirect) to different cost objects. In particular, the focus is on detecting the relationship between the costing choices used, which specify the implementation of the costing process in practice, with the main characteristics of the firm and the products produced.
\end{abstract}

The results suggest that, in Greece, the implementation of the costing process takes place in rather traditional contexts, maintaining a relatively modest, in complexity, costing system. The differences found in the cost structure and the characteristics of the products are not expected to cause significant difficulties in the cost allocation and the assignment process.

As expected, a positive correlation has been found between the size of the firm and the level of detailed recording of costing related information.

The argument that the diversification of the production process, as determined by the large number of products being produced, creates a need for more accurate and detailed cost recording system is also supported.

Finally, findings suggest that there is a negative correlation between the use of different allocation methods', for both internal and external accounting reports.

Keywords: cost system, cost allocation, firm size, type of production, Greek industrial firms.

\footnotetext{
${ }^{l}$ Department of Accounting and Finance, Technological Educational Institute (T.E.I.) of Thessaly, tsifora@teilar.gr

${ }^{2}$ Democritus University of Thrace, Faculty of Engineering, Department of Production and Management Engineering, pchatzog@pme.duth.gr
} 


\section{Introduction and theoretical background}

The primary objective of any cost system is to determine the production cost for the cost objects which are determined based on the needs of the firm. At the same time, managers pursuit multiple cost objectives, as evidenced using cost information in a variety of business decisions, and this something that is expected to have a significant impact on a cost system's general operation (Horngren et al., 2005; Rayburn, 1996; PAIB, 2009). One of the most important issues that such a system should deal with concerns the cost allocation or the assignment process, which is neither easy to be directly identified in different cost items nor is associated with multiple cost centres or functions (Biddle and Steinberg 1985; Dimitras and Ballas 2009; Tatsiopoulos et al., 2010; Liapis and Thalassinos, 2013).

In addition, a cost system is also affected by the organization and the actual operation of the production process. More specifically, the type of products (customized, standardized), the range of products (small or large number of different products) and the way that production process operates (automated, non-automated) are expected to affect the way that a cost system is organized and operates (Chen 1996; Fullerton and McWatters, 2004; Hilton, 2002; Rayburn, 1996). In a modern cost system, the effect of these characteristics is reflected by differences in the cost structure.

Particularly, during the last thirty years, the development of new production philosophies is evident through the integration of technological developments in the production process (Tsai, 1996) ${ }^{3}$. In practice, this differentiation is reflected as a reduction in the proportion of the direct labour costs and with an increase of the indirect costs, also known as overheads (Armostrong, 2002; Kee, 2008; Lowder, 2006). This observed "redistribution" has prompted a general question not only concerning the usefulness but, also, the suitability of the existing costing methodologies (Cooper and Kaplan, 1988; Gupta, 1993; Lere, 2001). The stronger criticism concerns the appropriateness of using allocation bases that are linked to direct labour. The significant reduction in the proportion of the direct labour, due to the automation of the production process, is probably the most critical point of negative criticism.

Similarly, the production of diversified products also entails variations in the demand and resource consumption, exacerbating the need for accuracy and detail regarding the level of overheads' absorption from products with a differentiated production volume. Computational and other types of errors are often in the above process, causing distortions in the calculation of cost figures (Abernethy et al., 2001, Cardinaels and Labro, 2009). Turning into choices, such as the implementation of multiple cost pools, is considered to improve the accuracy of cost estimations

\footnotetext{
${ }^{3}$ Based on Brimson (1986), Cooper and Kaplan (1988).
} 
(Heitger, 2007 as reported by Tse, 2011; Thalassinos and Liapis, 2014; Keisidou et al., 2013). In addition, diversified products have characteristics that often create the need for complex decision-making relatively to the resource planning, due to the complex interdependencies created between products and resources (Balakrishnan et al., 2011), making even more necessary the incorporation of precision, as a characteristic of the costing data used.

The primary task of a costing system is to collect the necessary cost related data (or information). The choices that a company use in terms of costing tools (methods techniques - practices), which can be incorporated into a costing system are numerous. However, the effectiveness of the cost system is affected by the appropriateness of the corresponding options. In other words, a costing system could not operate independently of the production process, or the corresponding production system (Tatsiopoulos et al., 2010). Additionally, features such as the needs and the business characteristics, as well as the individual features of the products produced, are determinant factors for choosing between alternatives as far as the implementation of the costing process is concerned.

Therefore, the design choices include specific features of the cost system, forming the content of cost data used by executives for decision-making (Ismail and Mahmoud, 2012). Although a uniform and generally acceptable approach concerning the designing choices cannot exist, the study of relevant literature makes evident that cost accumulation and allocation, as well as cost assignment at cost objects, are fundamental issues for any costing system (Abernethy et al., 2001, Al-Omiri and Drury, 2007; Brierley, 2010; Drury and Tales, 2005; Fisher and Krumwiede, 2012; Ismail and Mahmoud, 2012; Pizzini, 2006).

This empirical study investigates the relationship between costing choices used and the firm and product characteristics. Costing choices, such as (a) the use of different cost allocation methods; (b) the number of indirect cost allocation bases; (c) the number of allocation bases; (d) the number of cost pools; and (e) the type of cost pools, are explored. In this way, it is attempted to determine the form and strength of the relationship between the factors examined.

\section{Research methodology}

\subsection{Sample}

A field survey was conducted on a sample of Greek manufacturing firms, with sales turnover of more than $500.000 €$. The final sample consists of 598 manufacturing firms (a response rate of $45 \%$, considering the number of the firms that had initially agreed to participate in the survey and $16 \%$ response rate when the total population is considered).

According to Table 1, over $2 / 3(77 \%)$ of the participants were male, aged between $36-45(39.3 \%)$ or older $(34.8 \%)$, holding a higher education degree $(71.3 \%)$, even 
with a postgraduate or doctoral degree $(10.5 \%)$. The average experience of all participants was 17.7 years. Most of them work in the Accounting Department (56.9\%) or perform other administrative tasks $(33.8 \%)$, where some of them are Directors $(31.2 \%)$ or Supervisors $(43.4 \%)$ of their departments, while $22 \%$ of them are Managing Directors or General Managers. As far as their «in the job» experience, average they are in the current employee for 11.30 years, which shows that workers tend to pursue rather stable employment relationships.

Table 1. General respondents' characteristics

\begin{tabular}{|c|c|c|c|c|c|}
\hline $\begin{array}{l}\text { General } \\
\text { respondents' } \\
\text { characteristics }\end{array}$ & \multicolumn{5}{|l|}{ Answers } \\
\hline Gender $(\%)$ & \multicolumn{2}{|l|}{ Male $(\mathbf{7 7 \%})$} & \multicolumn{3}{|c|}{ Female $(\mathbf{2 3} \%)$} \\
\hline Age $(\%)$ & $\begin{array}{l}\text { Up to } 25 \\
(\mathbf{0 \%})\end{array}$ & $\begin{array}{c}26-35 \\
(\mathbf{2 5 . 9 \%})\end{array}$ & $\begin{array}{c}36-45 \\
(\mathbf{3 9 . 3 \%})\end{array}$ & $\begin{array}{c}46-55 \\
(\mathbf{2 4 . 8 \%})\end{array}$ & $\begin{array}{l}>55 \\
(\mathbf{1 0 \%})\end{array}$ \\
\hline $\begin{array}{l}\text { Educational level } \\
(\%)\end{array}$ & $\begin{array}{l}\text { High School } \\
(\mathbf{8 \%})\end{array}$ & $\begin{array}{l}\text { Techn.Educ. } \\
\text { Ins. } \\
(\mathbf{2 1 . 2 \% )}\end{array}$ & $\begin{array}{l}\text { University } \\
\mathbf{( 5 0 . 3 \% )}\end{array}$ & $\begin{array}{l}\text { Master } \\
\mathbf{( 1 8 . 8 \% )}\end{array}$ & $\begin{array}{l}\mathrm{PhD} \\
(\mathbf{1 . 7 \%})\end{array}$ \\
\hline $\begin{array}{l}\text { Total experience } \\
\text { (Mean) }\end{array}$ & \multicolumn{5}{|l|}{17.70 years } \\
\hline $\begin{array}{l}\text { Current position's } \\
\text { experience (Mean) }\end{array}$ & \multicolumn{5}{|l|}{$\mathbf{1 1 . 2 9}$ years } \\
\hline $\begin{array}{l}\text { Employment } \\
\text { department }(\%)\end{array}$ & $\begin{array}{l}\text { Production } \\
(\mathbf{8 . 5 \% )}\end{array}$ & $\begin{array}{l}\text { Accounting } \\
(\mathbf{5 6 . 9 \% )}\end{array}$ & $\begin{array}{l}\text { Admini- } \\
\text { stration } \\
\mathbf{( 3 3 . 8 \% )}\end{array}$ & $\begin{array}{l}\text { Other } \\
(\mathbf{0 . 8 \%})\end{array}$ & \\
\hline Position's title (\%) & $\begin{array}{l}\text { C.E.O. } \\
(\mathbf{1 3 . 7 \% )}\end{array}$ & $\begin{array}{l}\text { eneral } \\
\text { Ianager } \\
3.3 \% \text { ) }\end{array}$ & $\begin{array}{l}\text { rector } \\
1.2 \%)\end{array}$ & $\begin{array}{l}\text { Supervisor } \\
(\mathbf{4 3 . 4 \% )}\end{array}$ & $\begin{array}{l}\text { Other } \\
\mathbf{( 3 . 4 \% )}\end{array}$ \\
\hline
\end{tabular}

Table 2: General firms' characteristics

\begin{tabular}{|c|c|}
\hline General characteristics of the firms & Results \\
\hline Number of employees (mean) & $\begin{array}{l}\text { Administration department: } 33 \\
\text { Production department: } 78\end{array}$ \\
\hline Annual sales turnover (in , $000 €$ ) (mean) & $\begin{array}{l}\text { 2013: } 28,934.51 \\
\text { 2012: } 32,382.25\end{array}$ \\
\hline Sales distribution (2013) & $\begin{array}{l}\text { Up to } 1 \text { million: } 14.1 \% \\
\text { 1-5 millions: } 27.4 \% \\
\text { 5-20 millions: } 26.7 \% \\
\text { 20-50 millions: } 15.8 \% \\
\text { More than 50 million: } 16.1 \% \\
\end{array}$ \\
\hline Number of main products & $\begin{array}{l}\text { Up to 10: } 34.6 \% \\
\text { 11-50: } 26.7 \% \\
\text { 51-300: } 23.3 \% \\
\text { More than 300: } 15.4 \%\end{array}$ \\
\hline
\end{tabular}

The sample size of the participating firms is relatively representative of the size of Greek businesses (Table 2). 


\subsection{Questionnaire design}

A structured questionnaire was used as a research instrument for collecting primary data. It mainly consists of questions adopted from similar surveys found on the relevant literature (Tables 3-5). Therefore, every possible effort was taken to ensure the validity of the present survey. The questionnaire consists of the following parts: respondent's general information, general information on the firm (including cost elements), production data and a description of the costing system features.

The questionnaire was tested (pre-test) before it was released, to assess the degree of its content validity (Saunders et al., 2009). Such a test is used to check if the objectives of the research are correctly measured or captured. Consequently, the questionnaire was sent for a pre-test to three academics, five senior business executives (employed as cost accountants) and two chartered accountants. The main aim of this process was to realize whether the respondents perceived the terminology in a similar way (Dimitriadi, 1999).

Tables 3,4 and 5 analytically present the items used to determine the factors examined in the present study, as well as the supporting literature. Most of these questions are measured using a five-level scale (Likert type), where 1 indicated "absolute disagreement" and 5 "absolute agreement". The main features examined include the level of product standardization or diversification. In costing terms, when standardized products are mainly produced, the underlying conditions created establish a framework that makes the calculation of production costs a more standardized and familiar process to the executives of the enterprise. On the other hand, variations in some characteristics such as the volume of products produced and the use of services from other supporting departments, result in a more complicated and time-consuming cost allocation and assignment process. At the same time, the accuracy of the estimated costs is also affected while the complexity of the costing system is increasing as well (Alnestig and Segersted 1996; Lamminmaki and Drury, 2001; Lea and Fredendall, 2002). In addition, it causes variations in the cost structure, namely the ratio of the different cost categories (raw materials, direct labour and overhead).

\section{Descriptive statistical analysis results}

\subsection{Cost structure and production cost}

Table 6 includes the production's fundamental costing data for the companies participating in this research, such as the fixed and variable cost ratio, the direct and indirect cost ratio, and the production cost structure.

According to the findings, the ratio between fixed and variable costs is almost equal (Average $-48.11 \%$ and $49.92 \%$, respectively). On the contrary, the ratio between direct and indirect costs was found to be $2 / 3$ and $1 / 3$ (average $68.10 \%$ and $29.35 \%$ respectively). The above findings do not significantly differ from those of Al-Omiri and Drury (2007). Perhaps such a high proportion of direct costs suggests that firms 
may have ways to improve the visibility and accuracy of the calculated cost (Cinquini et al., 2013). In this way, there is a limited need for investment in complex and more sophisticated costing systems (Brierley et al., 2001, Major and Hopper 2005). Finally, regarding the cost structure, the results show that, on average, $60.45 \%$ refers to raw materials, while there is an almost equal ratio between direct labour costs $(19.41 \%)$ and overheads $(19.12 \%)$.

The above results seem to confirm the general assertion of a declining proportion in labour costs, mainly due to the automation of the production process (Bhimani and Bromwich, 1992) and are like those of Venieris and Cohen (2008) who have also examined Greek manufacturing firms. However, compared to those of Al-Omiri and Drury (2007), they differ especially regarding the overheads' ratio (33.8\%). Generally, for contemporary business environments, it seems that Kee's (2008) claim, that the proportion of labour cost is around 12\%, is confirmed. However, a significant differentiation $(33.8 \%)$ in the ratio of overheads (direct and indirect) may be justified due to the implementation of different philosophies and technologies in the production process (Lere, 2001; Lowder, 2006; Tsai, 1996), compared to those implemented in Greece. 
Table 3. Supporting literature for "Firm's characteristics"

\begin{tabular}{|c|c|c|}
\hline \multicolumn{3}{|c|}{ Factor: Firm's characteristics } \\
\hline \multicolumn{3}{|c|}{ Measurement: 6 questions to identify firm's features that might affect costing choices } \\
\hline Variables & Measurement description & References \\
\hline Firm’s size & $\begin{array}{l}2 \text { questions relatively to the number } \\
\text { of employers and turnover, during } \\
2012-2013 \text {. }\end{array}$ & $\begin{array}{l}\text { Lukka and Granlund 1996, Hoque } \\
\text { and James 2000, Chenhall 2003, } \\
\text { Drury and Tales 2005, } \\
\text { Krumwiede } \kappa \alpha \text { Suessmair 2006, } \\
\text { Schoute 2009. }\end{array}$ \\
\hline $\begin{array}{l}\text { Main } \\
\text { products }\end{array}$ & $\begin{array}{l}1 \text { question relatively to the number } \\
\text { of main products. }\end{array}$ & $\begin{array}{l}\text { Alnestig and Segersted 1996, Tsai } \\
1996 .\end{array}$ \\
\hline $\begin{array}{ll}\text { Fixed } & \text { and } \\
\text { variable } & \text { cost } \\
\text { rate } & \end{array}$ & $\begin{array}{l}1 \text { question relatively to the rate of } \\
\text { fixed and variable cost. }\end{array}$ & Oberholzer and Ziemerink, 2004. \\
\hline $\begin{array}{lr}\text { Direct } & \text { and } \\
\text { indirect } & \text { cost } \\
\text { rate } & \end{array}$ & $\begin{array}{l}1 \text { question relatively to the rate of } \\
\text { direct and indirect cost }\end{array}$ & Cohen and Kaymenaki, 2005. \\
\hline Cost structure & $\begin{array}{l}1 \text { question relatively to the rate of } \\
\text { materials cost, labour cost and } \\
\text { overheads }\end{array}$ & \\
\hline
\end{tabular}

Table 4. Supporting literature for the "Type of products"

\begin{tabular}{|c|c|c|}
\hline \multicolumn{3}{|c|}{ Factor: Type of the product } \\
\hline \multicolumn{3}{|c|}{$\begin{array}{l}\text { Measurement: } 7 \text { questions to determine the specific products' characteristics (standard } \\
\text { diversified) }\end{array}$} \\
\hline Variables & Measurement description & References \\
\hline $\begin{array}{l}\text { Standard } \\
\text { products }\end{array}$ & $\begin{array}{l}3 \text { questions relatively to the standardization of the } \\
\text { process. } \\
\text { 1. The firm produces only standard products } \\
\text { 2. The largest percentage of sales comes from standard } \\
\text { products } \\
\text { 3. The production process is flexible enough to provide } \\
\text { customers with a wide variety of products }\end{array}$ & $\begin{array}{l}\text { Kaymenaki } \\
(2008)\end{array}$ \\
\hline $\begin{array}{l}\text { Diversified } \\
\text { products }\end{array}$ & $\begin{array}{l}4 \text { questions relatively to the diversified production } \\
\text { process. } \\
\text { 1. There are significant differences between production } \\
\text { lines } \\
\text { 2. Design, production and distribution activities vary } \\
\text { considerably between products } \\
\text { 3. Production volume varies considerably between } \\
\text { production lines } \\
\text { 4. Between production lines, the use of services by the } \\
\text { support departments varies considerably }\end{array}$ & $\begin{array}{l}\text { Kaymenaki } \\
(2008)\end{array}$ \\
\hline
\end{tabular}

Table 5. Supporting literature for the «Cost system features» 


\begin{tabular}{|c|c|c|}
\hline \multicolumn{3}{|c|}{ Factor: Identification of cost system features } \\
\hline \multicolumn{3}{|c|}{ Measurement: 5 questions relatively to the cost system features } \\
\hline Variables & $\begin{array}{l}\text { Measurement } \\
\text { description }\end{array}$ & References \\
\hline $\begin{array}{l}\text { Diversified allocation methods } \\
\text { based on the needs (Financial } \\
\text { Accounting - Internal audit). }\end{array}$ & 1 question & Krumwiede and Suessmair, 2006 \\
\hline $\begin{array}{l}\text { Indirect cost allocation (plant- } \\
\text { wide or departmental allocation } \\
\text { bases). }\end{array}$ & 1 question & $\begin{array}{l}\text { Drury 2000, Drury and Tales 2005, } \\
\text { Krumwiede and Suessmair } 2006 .\end{array}$ \\
\hline Number of allocation bases. & 1 question & Schoute, 2009. \\
\hline Number of cost pools. & 1 question & $\begin{array}{l}\text { Drury and Tales 2005, Krumwiede } \\
\text { and Suessmair 2006, Al-Omiri and } \\
\text { Drury 2007, Schoute } 2009 \text {. }\end{array}$ \\
\hline Type of cost driver used. & 1 question & $\begin{array}{l}\text { Drury 2000, Brierley et al., 2001, } \\
\text { Drury and Tales 2005, Venieris and } \\
\text { Cohen 2007, Wihinen } 2012 \text {. }\end{array}$ \\
\hline
\end{tabular}

Table 6. Cost proportion and cost structure

\begin{tabular}{|c|c|c|c|c|}
\hline Variables & Variable values & $\begin{array}{l}\text { Percentage } \\
(\%)\end{array}$ & $\begin{array}{l}\text { Cumulative } \\
\text { Percentage } \\
\%\end{array}$ & Mean \\
\hline \multirow{8}{*}{ Proportion of fixed cost } & $0-10 \%$ & $7.9 \%$ & $7.9 \%$ & \multirow{8}{*}{48,11} \\
\hline & $10-20 \%$ & $10.4 \%$ & $18.3 \%$ & \\
\hline & $21-30 \%$ & $20.9 \%$ & $39.2 \%$ & \\
\hline & $31-40 \%$ & $8.7 \%$ & $47.9 \%$ & \\
\hline & $41-50 \%$ & $9.2 \%$ & $57.1 \%$ & \\
\hline & $51-70 \%$ & $21.2 \%$ & $78.3 \%$ & \\
\hline & $71-80 \%$ & $12.5 \%$ & $90.8 \%$ & \\
\hline & $81-100 \%$ & $9.2 \%$ & $100 \%$ & \\
\hline \multirow{8}{*}{$\begin{array}{l}\text { Proportion of variable } \\
\text { cost }\end{array}$} & $0-10 \%$ & $6.3 \%$ & $6.3 \%$ & \multirow{8}{*}{49,32} \\
\hline & $10-20 \%$ & $17.5 \%$ & $23.8 \%$ & \\
\hline & $21-30 \%$ & $12.2 \%$ & $36.0 \%$ & \\
\hline & $31-40 \%$ & $10.0 \%$ & $46.0 \%$ & \\
\hline & $41-50 \%$ & $7.1 \%$ & $53.1 \%$ & \\
\hline & $51-70 \%$ & $23.9 \%$ & $77.0 \%$ & \\
\hline & $71-80 \%$ & $11.7 \%$ & $88.7 \%$ & \\
\hline & $81-100 \%$ & $11.3 \%$ & $100 \%$ & \\
\hline \multirow{6}{*}{$\begin{array}{l}\text { Proportion of direct } \\
\text { cost }\end{array}$} & $0-20 \%$ & $4.8 \%$ & $4.8 \%$ & \multirow{6}{*}{68,10} \\
\hline & $20-40 \%$ & $8.8 \%$ & $13.6 \%$ & \\
\hline & $41-50 \%$ & $6.6 \%$ & $20.2 \%$ & \\
\hline & $51-60 \%$ & $10.9 \%$ & $31.1 \%$ & \\
\hline & $61-70 \%$ & $22.0 \%$ & $53.1 \%$ & \\
\hline & $71-80 \%$ & $23.7 \%$ & $76.8 \%$ & \\
\hline
\end{tabular}




\begin{tabular}{|c|c|c|c|c|}
\hline & $81-90 \%$ & $14.0 \%$ & $90.8 \%$ & \\
\hline & $91-100 \%$ & $9.2 \%$ & $100 \%$ & \\
\hline \multirow{6}{*}{$\begin{array}{l}\text { Proportion of indirect } \\
\text { cost }\end{array}$} & $0-10 \%$ & $18.0 \%$ & $18.0 \%$ & \multirow{6}{*}{29,35} \\
\hline & $11-20 \%$ & $25.4 \%$ & $43.4 \%$ & \\
\hline & $21-30 \%$ & $25.0 \%$ & $68.4 \%$ & \\
\hline & $31-40 \%$ & $12.7 \%$ & $81.1 \%$ & \\
\hline & $41-50 \%$ & $7.5 \%$ & $88.6 \%$ & \\
\hline & More than $50 \%$ & $11.4 \%$ & $100 \%$ & \\
\hline
\end{tabular}

However, the findings regarding the direct labour cost $(19.41 \%)$ significantly differ (10\%) compared to the results of other similar surveys (Szendi and Elmore 1993, as reported by Reinstein and Bayou 1997). This could be interpreted in two ways:

(a) labour costs in Greece are higher than those included in the above survey;

(b) in Greece, businesses are more labour-intensive and investments in modern automation is lower compared to other countries.

Although it is not unusual to notice significant differences on the findings of such surveys (Brierley et al., 2001), it seems that for Greek firms, there is an additional point of differentiation. The non-confirmation of overheads' significance, as a proportionally larger cost compared to the direct labour cost, could be regarded as an unexpected finding. However, it is possible this to stem from the way that products are differentiated, especially, when their production process involves not only significant modifications to the raw materials used, but, also, engine's restart (lead) times. Eventually, such conditions may lead to a more complex production process and an increase of the overheads (Abernethy et al., 2001; Tsai 1996).

As far as the findings concerning the percentage between direct and indirect production costs, they show that $76.8 \%$ of the firms have a direct cost ratio of up to $80 \%$, which means that the indirect costs are proportional around $20 \%$. More generally, since indirect costs cannot be clearly and accurately identified and measured in each cost item then, it might cause difficulties in the costing process, forcing the firm to find alternative ways for its allocation. Of course, the smaller its participation to the total production cost, the less likely is the appearance of various cost distortions, originated from the lack of accuracy during its assignment.

\subsection{Production characteristics}

The identification of the specific product characteristics, as well as the way the production function is generally organized, was attempted through the "evaluation" of specific features. Table 7 shows the mean score (and the standard deviation) for each of the examined features, with a hierarchical rank from highest to lowest. 
Table 6 (cont.). Cost proportion and cost structure

\begin{tabular}{|c|c|c|c|c|}
\hline Variables & Variable values & $\begin{array}{l}\text { Percentage } \\
(\%)\end{array}$ & $\begin{array}{l}\text { Cumulative } \\
\text { Percentage } \\
\% \\
\end{array}$ & Mean \\
\hline $\begin{array}{l}\text { Proportion of direct } \\
\text { materials' cost }\end{array}$ & $\begin{array}{l}0-20 \% \\
20-40 \% \\
41-50 \% \\
51-60 \% \\
61-70 \% \\
71-80 \% \\
81-90 \% \\
91-100 \% \\
\end{array}$ & $\begin{array}{l}4.3 \% \\
14.3 \% \\
14.0 \% \\
19.0 \% \\
20.1 \% \\
14.7 \% \\
10.5 \% \\
3.1 \% \\
\end{array}$ & $\begin{array}{l}4.3 \% \\
18.6 \% \\
32.6 \% \\
51.6 \% \\
71.7 \% \\
86.4 \% \\
96.9 \% \\
\mathbf{1 0 0 \%} \\
\end{array}$ & 60,45 \\
\hline $\begin{array}{l}\text { Proportion of direct } \\
\text { labour cost }\end{array}$ & $\begin{array}{l}0-5 \% \\
6-10 \% \\
11-15 \% \\
16-20 \% \\
21-25 \% \\
26-30 \% \\
31-70 \%\end{array}$ & $\begin{array}{l}12.0 \% \\
24.3 \% \\
10.8 \% \\
19.3 \% \\
8.1 \% \\
12.4 \% \\
13.1 \% \\
\end{array}$ & $\begin{array}{l}12.0 \% \\
36.3 \% \\
47.1 \% \\
66.4 \% \\
74.5 \% \\
86.9 \% \\
\mathbf{1 0 0 \%} \\
\end{array}$ & 19,41 \\
\hline $\begin{array}{l}\text { Proportion of overhead } \\
\text { cost }\end{array}$ & $\begin{array}{l}0-5 \% \\
6-10 \% \\
11-15 \% \\
16-20 \% \\
21-25 \% \\
26-30 \% \\
31-70 \%\end{array}$ & $\begin{array}{l}10.5 \% \\
22.8 \% \\
15.5 \% \\
21.0 \% \\
7.3 \% \\
8.9 \% \\
14.0 \%\end{array}$ & $\begin{array}{l}10.5 \% \\
33.3 \% \\
48.8 \% \\
69.8 \% \\
77.1 \% \\
86.0 \% \\
100 \%\end{array}$ & 19,12 \\
\hline
\end{tabular}

Table 7. Products' characteristics diversification

\begin{tabular}{|l|r|c|}
\hline Production characteristics & Mean & S.D. \\
\hline $\begin{array}{l}\text { The production process is flexible enough to provide customers with a } \\
\text { wide variety of products. }\end{array}$ & 4.06 & 1.065 \\
The majority of sales come from standard products. & 3.33 & 1.532 \\
\hline The company produces only standard products. & 3.08 & 1.592 \\
\hline $\begin{array}{l}\text { Production volume varies considerably between production lines. } \\
\text { Production lines show significant differences between them. }\end{array}$ & 3.02 & 1.224 \\
\hline $\begin{array}{l}\text { The activities of product design, production and distribution vary } \\
\text { considerably between products. }\end{array}$ & 2.57 & 1.295 \\
\hline $\begin{array}{l}\text { The use of services provided by the supporting departments varies } \\
\text { considerably between production lines. }\end{array}$ & 2.49 & 1.183 \\
\hline
\end{tabular}

The exploration of product's degree of differentiation, i.e. the level of standardization or customization in their features, is important because it affects the cost flow and, consequently, the method used for collecting cost data (Garrison and Noreen, 2006). Additionally, product diversification in terms of production volume, production lines, or even the degree of innovation incorporated in the products, is expected to affect the practical implementation of the costing procedure, as well as 
the company's available choices when collecting the cost data (Cinquini et al., 2013). Producing many different products not only requires more resources to be consumed (Kellermanns and Islam, 2004), but also might create interactions that are expected to affect each individual product's total cost, especially when economies of scale are present.

About the determination of the products' level of differentiation, it appears that the participating firms are mainly selling and producing standard products (mean: 3.33 and 3.08 respectively). However, the relatively high standard deviation probably imply that there are significant differences in the homogeneity of the product characteristics, resulting in a mix of standardized and customized products, based on rather flexible production processes. Finally, at least for some companies, the production volume does not appear to be significantly different among various production lines.

A similar picture emerges considering the findings concerning the level of small differentiation in the design, production and distribution activities, between production lines, as well as the usage of supporting services.

\subsection{Methods and process of allocation}

The differentiation in the allocation methods, which will allow them to better satisfy the financial accounting and internal auditing needs, is the main choice of almost three out of four firms $(72.5 \%)$ in the sample. The above finding may imply either that the needs arising from the obligation for external reporting (a compulsory and inevitable task) are likely to be predominant, or that the current information systems assist the process of transforming costing data according to the executive's needs.

In general, the main reason for the emergence of the allocation problem is the presence of cost that is associated with many different cost centres or functions. The combined use of allocation rates and allocation sheets is a frequent choice $(42.7 \%)$ for Greek companies, although $29.7 \%$ of them use only the allocation sheets, while $27.6 \%$ directly allocate costs by using predetermined allocation rates. Probably, the limited rate of the utilization of the predetermined allocation rates is due to the need of adjusting accounting differences which arise at the end of the fiscal period, particularly when the firm uses budgeted rather than actual figures (Dimitras and Ballas, 2009).

Over half of the participating firms (57.4\%) use separate allocation rates for indirect costs, which are determined departmentally. The existence of separate allocation rates is expected to promote the accuracy of the calculated figures (Krumwiede and Suessmair, 2006), while maintaining a modest degree of complexity for the costing system (Schoute, 2009). Such a choice is probably stimulated by differentiations in the products and their corresponding cost centres (Dimitras and Ballas, 2009). 
The mean of number of allocation bases used by firms found to be 4.26 , with up to 3 bases used by $68.7 \%$ of them. Compared to other surveys (Al-Omiri and Drury, 2007), the relatively small number of bases used may underline the effort of these firms to maintain a balance between the degree of precision and easiness when collecting cost data, implying that they rather prefer to use traditional cost systems (Schoute, 2009). Alternatively, it could be due to their effort to maintain a moderate level of complexity, as well as to limit and control a system's maintenance costs (Cinquini et al., 2013), without negatively affecting the accuracy of the costing process.

Further, it is revealed that, on average, the number of cost pools used is around 7.53. Compared to other similar surveys ${ }^{4}$ (Al-Omiri and Drury, 2007), this number is much smaller, while over three-quarters of the firms $(80.6 \%)$ use up to 6 different cost pools, revealing the use of cost systems with a medium level of complexity (Drury and Tales, 2005). In any case, the provided level of accuracy of the collected cost information is not adversely affected.

On the contrary, according to Balakrishnan et al. (2011), the use of more than 10-15 cost pools may have a negative impact. Moreover, more than half of companies (58.5\%) use transaction cost drivers for measuring activities. Duration cost drivers, which are considered to provide more accurate cost data and characterize more sophisticated cost systems (Al-Sayed and Dugdale, 2016), are used by $26.1 \%$ of the firms. Finally, intensity cost drivers are used only by $16.2 \%$ of the firms. Probably, this low rate is justified by the increased difficulty in calculating such types of cost drivers, while the increased level of difficulty is not balanced by a higher costing accuracy (Drury 2000; Venieris and Cohen 2007; Wihinen, 2012).

\section{Data analysis and results}

\subsection{Costing choices used and product type}

The results of the correlation analysis between the costing options used (differences in the allocation methods, number of indirect cost allocation rates, number of cost allocation bases, number of cost pools and the type of cost driver used) and the product type (standardized products and differences in the production process) are presented in Table 8. The examination of the results reveals that the production of products with different characteristics is the main factor which is associated to the adoption of specific costing choices, providing a picture of the implementation of the production process in practice.

More specifically, statistically significant positive correlations were found between the diversified production process and: a) the number of indirect cost allocation rates

\footnotetext{
${ }^{4}$ However, most of those surveys included firms implementing Activity Based Costing A.B.C.
} 
$(\mathrm{r}:$,292), b) the number of cost allocation bases (r: ,254) and c) the number of cost pools (r: ,250). Also, it is significantly (negatively) correlates with the use of diversified allocation methods ( $\mathrm{r}$ : - ,175). It is should be reminded that the use of different allocation methods is triggered by the different obligation to satisfy needs, when compiling of external and internal reports.

The production of diversified goods may entail variations in demand and resource consumption, especially when diversification is also observed in terms of production volume. In such circumstances, errors are often introduced, resulting in distorted cost figures calculation. Consequently, there is an increased need for accuracy and precision regarding the overheads' absorption level (Abernethy et al., 2001, Cardinaels and Labro, 2009). Features, such as the use of multiple cost pools, improve the accuracy of estimates (Heitger 2007, as reported by Tse 2011). Frequently, the diversified production requires complex decisions especially on the planning of resources used (Balakrishnan et al., 2011), creating a pressing need for precision in the estimated costing figures.

Also, a statistically significant positive relationship (r: 289) seems to exist between the number of different if the allocation rates are determined departmentally, for achieving higher accuracy in the calculated cost. In other words, more cost pools will better capture the variation in the consumption of resources by the cost objects (AlOmiri and Drury, 2007). In addition, the use of more allocation bases can also improve the ability of the system to capture causation in the calculated costing figures (Schoute, 2009). allocation bases and the number of rates used for allocating indirect costs. Even stronger $(\mathrm{r}:, 415)$ seems to be the relationship between the number of cost pools and the number of allocation bases. These findings were expected, as the increase in the number of bases used, aiming to a better indirect costs allocation, will also increase the number of the allocation rates used. In practice, this implies a different rate for each allocation. 
Table 8. Correlation analysis results (between the costing choices and the type of products)

\begin{tabular}{|c|c|c|c|c|c|c|c|c|}
\hline & & $\begin{array}{l}\text { Use of different } \\
\text { allocation methods }\end{array}$ & $\begin{array}{c}\text { Number of } \\
\text { indirect } \\
\text { allocation rates }\end{array}$ & $\begin{array}{c}\text { Number of } \\
\text { allocation } \\
\text { bases }\end{array}$ & $\begin{array}{l}\text { Number of cost } \\
\text { pools }\end{array}$ & $\begin{array}{l}\text { Cost drivers } \\
\text { based on } \\
\text { transactions }\end{array}$ & $\begin{array}{c}\text { Cost drivers } \\
\text { based on } \\
\text { duration }\end{array}$ & $\begin{array}{c}\text { Cost drivers } \\
\text { based on } \\
\text { intensity }\end{array}$ \\
\hline \multirow{2}{*}{$\begin{array}{l}\text { Use of different allocation } \\
\text { methods }\end{array}$} & Correl. Coeff. & 1,000 & & & & & & \\
\hline & Sig. (2-tailed) & & & & & & & \\
\hline \multirow[t]{2}{*}{ Number of allocation rates } & Correl. Coeff. & & 1,000 & & & & & \\
\hline & Sig. (2-tailed) & & & & & & & \\
\hline \multirow[t]{2}{*}{ Number of allocation bases } & Correl. Coeff. & &, 289 & 1,000 & & & & \\
\hline & Sig. (2-tailed) & &, 003 & & & & & \\
\hline \multirow[t]{2}{*}{ Number of cost pools } & Correl. Coeff. & & & 415 & 1,000 & & & \\
\hline & Sig. (2-tailed) & & &, 000 & & & & \\
\hline \multirow{2}{*}{$\begin{array}{l}\text { Cost drivers based on } \\
\text { transactions }\end{array}$} & Correl. Coeff. & & & & & 1,000 & & \\
\hline & Sig. (2-tailed) & & & & & & & \\
\hline \multirow[t]{2}{*}{ Cost drivers based on duration } & Correl. Coeff. & & & & &,- 691 & 1,000 & \\
\hline & Sig. (2-tailed) & & & & &, 000 & $\cdot$ & \\
\hline \multirow[t]{2}{*}{ Cost drivers based on intensity } & Correl. Coeff. & & & &,- 218 &,- 503 &,- 182 & 1,000 \\
\hline & Sig. (2-tailed) & & & &, 033 &, 000 &, 020 & \\
\hline \multirow[t]{2}{*}{ Standardized products } & Correl. Coeff. & & & & & & & \\
\hline & Sig. (2-tailed) & & & & & & & \\
\hline \multirow[t]{2}{*}{ Diversified products } & Correl. Coeff. &,- 175 &, 292 &, 254 &, 250 & & & \\
\hline & Sig. (2-tailed) &, 017 &, 000 &, 010 &, 011 & & & \\
\hline
\end{tabular}


Finally, there is a statistically significant negative relationship between the use of different types of cost drivers. In particular, both duration and intensity-based cost drivers are negatively related to transaction-based cost drivers ( $\mathrm{r}:-, 691$ and $\mathrm{r}:-, 503$ respectively). The role of cost drivers is to measure the intensity and frequency that the cost objects consume the resources. However, due to their different operation mode, for every driver used, significantly variations are expected to the amount of the calculated cost (Krumwiede et al., 2013). The selection of an appropriate cost driver affects the quality of cost information, through the degree of integration of the causality, which links the expense to the unit cost (Kellermanns and Islam, 2004). The previous finding is also linked to the existence of a negative correlation (r:,218) between the use of intensity cost drivers and the number of cost pools used. The adoption of an "intensive" cost-driver leads to a direct allocation of the actual resources used by a given activity, reducing the need for gathering cost elements with similar behaviour to cost pools, and limiting the need for indirect allocation.

\subsection{Costing choices applied and production's cost structure}

Table 9 presents the results of the correlation analysis between the costing choices and the components of the production cost (the ratios between fixed and variable cost, direct and indirect cost and raw materials, direct labour and overheads). Such an analysis seeks to explore the way that various characteristics of the production structure influence the implementation of the costing process. Concerning the aforementioned issue, there is a pervasive view that features, such as the higher proportion of indirect costs, create a need for a more sophisticated costing system, in order to reduce the risk of cost distortions. However, there are no corresponding findings confirming the above claim (Brierley, 2008).

The statistically significant negative association $(\mathrm{r}:-, 143)$ between the proportion of direct labour and the use of different allocation methods for internal and external reports (Table 9) was expected. Since direct costs can be easily and accurately tracked for each cost object (Cinquini et al., 2013), therefore, it is not necessary to collect and calculate different costing data for the preparation of various costing reports.

Additionally, the type of the cost object selected can affect the accuracy of the collected costing information. More analytically, the wider a cost object is (machine centre, production line, factory or company) then, the larger proportion of direct to total cost is expected (Fixson, 2004). In general, cost traceability is thought to improve accuracy of the collected costing data.

The above argument is consistent with the statistically significant positive relationship $(\mathrm{r}:, 163)$ found between the overheads proportion and the number of indirect cost allocation drivers. 
Table 9. Correlation analysis results (between the costing choices and the production cost)

\begin{tabular}{|c|c|c|c|c|c|c|c|c|}
\hline & & $\begin{array}{c}\text { Use of } \\
\text { different } \\
\text { allocation } \\
\text { methods }\end{array}$ & $\begin{array}{c}\text { Number of } \\
\text { indirect } \\
\text { allocation } \\
\text { rates }\end{array}$ & $\begin{array}{c}\text { Number of } \\
\text { allocation } \\
\text { bases }\end{array}$ & $\begin{array}{c}\text { Number } \\
\text { of cost } \\
\text { pools }\end{array}$ & $\begin{array}{l}\text { Cost drivers } \\
\text { based on } \\
\text { transactions }\end{array}$ & $\begin{array}{c}\text { Cost drivers } \\
\text { based on } \\
\text { duration }\end{array}$ & $\begin{array}{c}\text { Cost } \\
\text { drivers } \\
\text { based on } \\
\text { intensity }\end{array}$ \\
\hline \multirow{2}{*}{$\begin{array}{l}\text { Proportion of fixed cost to total } \\
\text { production cost }\end{array}$} & Correl. Coeff. & & & & &,- 261 & &, 270 \\
\hline & Sig. (2-tailed) & & & & &, 002 & &, 001 \\
\hline \multirow{2}{*}{$\begin{array}{l}\text { Proportion of variable cost to total } \\
\text { production cost }\end{array}$} & Correl. Coeff. & & & & &, 219 & &,- 274 \\
\hline & Sig. (2-tailed) & & & & &, 008 & &, 001 \\
\hline \multirow[t]{2}{*}{ Proportion of direct production cost } & Correl. Coeff. & & & & & & & \\
\hline & Sig. (2-tailed) & & & & & & & \\
\hline \multirow{2}{*}{$\begin{array}{l}\text { Proportion of indirect production } \\
\text { cost }\end{array}$} & Correl. Coeff. & & & & & & & \\
\hline & Sig. (2-tailed) & & & & & & & \\
\hline \multirow{2}{*}{$\begin{array}{l}\text { Production cost structure - Direct } \\
\text { materials }\end{array}$} & Correl. Coeff. & & & & & & & \\
\hline & Sig. (2-tailed) & & & & & & & \\
\hline \multirow{2}{*}{$\begin{array}{l}\text { Production cost structure - Direct } \\
\text { labour }\end{array}$} & Correl. Coeff. &,- 143 & & & &,- 140 & &, 181 \\
\hline & Sig. (2-tailed) & .053 & & & &, 076 & &, 021 \\
\hline \multirow{2}{*}{$\begin{array}{l}\text { Production cost structure - } \\
\text { Overheads }\end{array}$} & Correl. Coeff. & & 163 & &,- 170 & & & \\
\hline & Sig. (2-tailed) & &, 026 & &, 088 & & & \\
\hline
\end{tabular}


Since, by definition, fixed production cost remains unaffected by changes in the production volume, it is expected to be negatively related to transaction-based cost drivers $^{5}$ (r: - ,261). Similarly, the nature of direct labour costs does not allow an accurate measurement and interpretation based on transaction-based cost drivers (statistically significant negative relationship, r: -,140), but it is rather improved with intensity-based cost drivers. In any case, choosing the proper cost driver contributes towards having a more accurate costing information. Specifically, the identification of intensity drivers, such as the time required to perform an activity, can be estimated with precision and easiness based on the employees' employment cards, a claim that is confirmed by the findings, e.g. the existence of a statistically significant positive correlation $(\mathrm{r}:, 181)$ between direct labour costs and intensity-based cost drivers.

Correspondingly, the variable cost outflow is usually caused by a change in the volume of transactions and, therefore, it is positively correlated with transactionbased costs drivers (r: ,219) and negatively with cost drivers based on intensity (r: ,274). Regarding fixed production cost, it can be accurately calculated and attributed directly to cost objects. Therefore, in the short term, there is not an imperative need for its measurement using corresponding cost drivers (Udpa, 2001). However, our results indicate the existence of a statistically significant positive correlation (r: ,270) between the proportion of fixed product cost and the intensity-based cost drivers.

\subsection{Firm's size and costing choices}

A statistically significant positive correlation (Table 10) was also found between firm's size determinant parameters (number of administration and production employees', sales) and the characteristics of the costing system, forming the level of detail, accuracy and complexity for the costing system, with stronger correlations concerning the number of allocation bases and cost pools. Finally, a negative correlation was revealed between firm size and cost drivers based on intensity, probably implying that the choice of this type of cost drivers is a managerial decision, which does not necessarily require the availability of the necessary firm resources.

Table 10. Correlation analysis results (between the costing choices and the characteristics of firm)

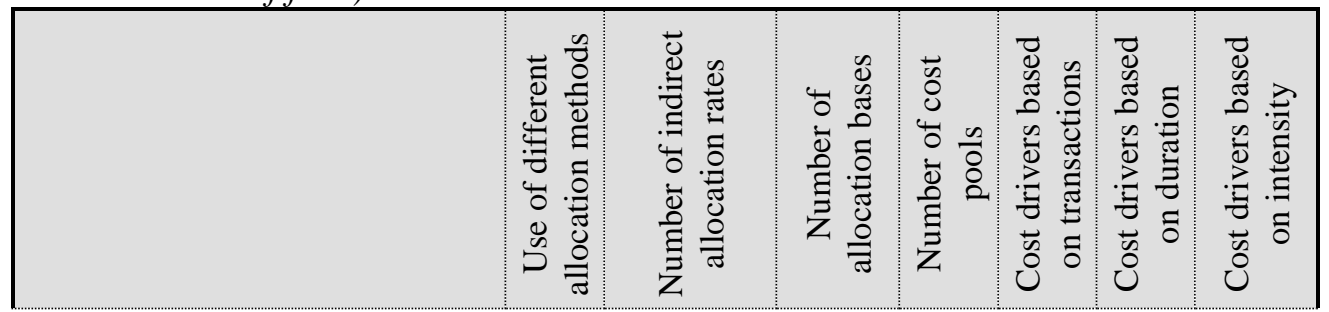

\footnotetext{
${ }^{5}$ Transaction-based cost drivers represent the number of times that an activity is executed (Ben-Ariel and Qian, 2003).
} 


\begin{tabular}{|c|c|c|c|c|c|c|}
\hline \multirow{2}{*}{$\begin{array}{l}\text { Number of } \\
\text { employees } \\
\text { (administration } \\
\text { department) }\end{array}$} & Correl. Coeff. &, 215 & ,393 & ,416 &, 150 &,- 246 \\
\hline & Sig. (2-tailed) &, 004 &, 000 & ,000 & ,059 & ,002 \\
\hline \multirow{2}{*}{$\begin{array}{l}\text { Number of } \\
\text { employees } \\
\text { (production } \\
\text { department) }\end{array}$} & Correl. Coeff. & ,207 & , 415 & ,430 & &,- 230 \\
\hline & Sig. (2-tailed) &, 005 &, 000 & ,000 & & ,004 \\
\hline \multirow[t]{2}{*}{$\begin{array}{l}\text { Sales turnover } \\
2013\end{array}$} & Correl. Coeff. &, 171 & ,368 & ,299 & &,- 261 \\
\hline & Sig. (2-tailed) & ,021 &, 000 & ,003 & &, 001 \\
\hline \multirow{2}{*}{$\begin{array}{l}\text { Size (based on } \\
\text { sales distribution) }\end{array}$} & Correl. Coeff. &, 223 & , 425 &, 396 & &,- 203 \\
\hline & Sig. (2-tailed) &, 002 &, 000 &, 000 & & ,009 \\
\hline \multirow{2}{*}{$\begin{array}{l}\text { Number of } \\
\text { products }\end{array}$} & Correl. Coeff. &, 135 & ,245 &, 334 & & \\
\hline & Sig. (2-tailed) &, 068 & 013 & ,001 & & \\
\hline
\end{tabular}

\section{Conclusions, limitations and future research}

Based on the above general findings, it could be claimed that the costing process in Greece is implemented rather traditionally, maintaining a not particularly complicated costing system. However, taking into account the cost structure and the characteristics of the products, it is not expected that someone would face significant difficulties concerning the allocation and assignment procedure (Grasso 2005, Lamminmaki and Drury 2001).

It seems that differences in the production process do not always have a clear impact on the costing system's level of complexity (Krumwiede et al., 2013). The diversification of production appears to affect the characteristics of the costing system, mainly due to the increased complexity of the interlocking processes. This may cause malfunctions and problems (Karmarkar and Pitbladdo, 1994), especially owing to the fact that more resources and activities are required for their production. At the same time, an increase in the proportion of indirect costs is expected (Brierley, 2008). In this way, the complexity of the production mix and the desired level of precision may create the need to use more cost drivers in order to avoid cost distortions (Krumwiede et al., 2013).

Usually, in a costing system, the complexity of production processes is reflected to the presence of different cost pools, while diversified products imply multiple allocation bases (Alnestig and Segersted, 1996). In any case, the need of improving and increasing the visibility and accuracy of the estimated costs (Kaplan and Cooper 1998, as reported by Wihinen 2012) is being achieved through the increased number of bases and cost pools used, for allocating indirect costs (Drury and Tales 1997, Brierley et al., 2001). The above assertions are also confirmed in the case of the 
Greek firms examined, indicating that the aforementioned features do not only exist in a costing system, especially when non-customized goods are produced, but they are also considered to be useful and necessary for them.

On the contrary, the increased complexity, stemming from diversified production, creates inhibiting conditions for using different costing data, which meet internal and external reporting needs. It is likely that the additional burden created when an executive should calculate costing data differently, for a specific decision or purpose, is not considered as particularly necessary or useful. Therefore, for a firm already facing significant and not limited complexity, caused by the implemented production process, the burden resulting from calculating additional cost figures is undesirable. As a result, under these circumstances, the implementation of a single and uniform cost allocation method for both official and internal reports may be considered an one-way solution.

Further, an interesting finding regards the use of different (departmental) allocation rates as far as the overheads are concerned. The inability to directly trace overheads makes the accurate assignment of costs to different cost objects a very difficult task. Consequently, the visibility and accuracy of such cost is expected to be improved by using more indirect cost allocation rates, especially when the proportion of common (indirect) overheads to total cost is high.

Although the use of intensity drivers increases the complexity of a costing system, since they presuppose the existence of "mechanisms" that measure the actual consumption of resources used by an activity (Gunasekaran et al. 2005, Fisher and Krumwiede 2012), however, Kaplan and Cooper (1998) (as reported by Brierley, 2008) propose the adoption of this type of cost driver for directly allocating overheads to products. The findings have yet to confirm such a relationship, probably due to the desire to maintain a moderate level of complexity.

The relationships found between fixed and variable costs and the type of cost driver used (based on transactions and intensity) may be justified by the appropriate use of cost data for different purposes or business decisions. Firms often take decisions over a different time horizon while, in the long run, a distinction between fixed and variable costs does not exist in practice (Fixson, 2004). Usually, for short-term decisions, fixed cost should not be taken into account (Friedl et al. 2005, Kee 2008, Laminmaki and Drury 2001). On the contrary, in the long run, ignoring fixed costs can lead to mistaken decisions, while their impact could even affect the viability of the firm (Schildbach, 1997).

Regarding the impact of firm size, it was found that, in most cases, larger firms have more available resources (time, staff), for tracing and recording the cost figures in detail (Chenhall 2003, Drury and Tales 2005, Ismail and Mahmoud 2012). Also, a diversified production process, as determined by the largest number of products, raises the need for more accurate cost tracing. 
It is normal that each firm is a completely different organization compared to any other, even similar firm. Differences in the size, industry, production organization and management and cost structure are very common. However, such differences set a fundamental limitation when generalizing conclusions (Al-Sayed and Dugdale, 2016). Although the sample of current research includes only manufacturing firms, it is likely for them to be heterogeneous, especially regarding their size and industry sector (Abdel-Kader and Luther 2008, Brierley 2010, Ismail and Mahmoud 2012). Especially, examining the size, the majority of the firms in the current survey could be characterized as small and medium. This feature might restrict both the generalizability and the reliability of the findings, as far as their application to larger firms is concerned. At the same time, the impact of the "industry" factor (Gosselin, 1997) was not examined. Similarly, the impact of the location of the firms' headquarters on the costing features examined could be significant, since, larger urban centres are more likely to employ qualified cost accountants, who have the opportunity to exchange views and knowledge, and in this way to facilitate the diffusion of the relevant innovations.

Another common limitation to cross-sectional studies refers to their ability to formulate associations, but not causality. In addition, there is always the possibility for significant variables to be excluded (omitted variables) (Schoute, 2009). Also, it is particularly important to consider the fact of introducing bias, in cases that there is a lack of understanding of the terminology used (Krumwiede et al., 2013, Shil et al., 2015). Also, the fact that for each firm there was only one respondent who, in the majority of cases (according to table 1), held an accountant's position, may introduce a common method bias regardless the fact that he could be an expert in the issues explored (Schoute, 2009).

In the future, one could study the effect of the decisions' time horizon (short or longterm) on the costing choices. For example, the choice of producing a specific product, or the selection of the production mix, especially if these results in increased indirect costs, make necessary and, at the same time, more difficult to trace cost to specific products (Fritzsch, 1997). Also, the impact of factors, such as size, number of products, industry and differentiation about the costing purposes pursued, on the practical implementation of the costing process could be explored. In this way, not only the theoretical background would be academically enriched, at least for the specific topic, but it would be possible to build a bridge and align the academic community with practitioners and firm management.

\section{References:}

Abdel-Kader, M. and Luther, R. 2008. The impact of firm characteristics on management accounting practices: A UK-based empirical analysis. The British Accounting Review, 40(1), 2-27.

Abernethy, M.A., Lillis, A.M., Brownell, P. and Carter, P. 2001. Product diversity and costing system design choice: field study evidence. Management Accounting Research, 12(3), 261-279. 
Alnestig, P. and Segersted, A. 1996. Product costing in ten Swedish manufacturing companies. International Journal of Production Economics, 46, 441-457.

Al-Omiri, M. and Drury, C. 2007. A survey of factors influencing the choice of product costing systems in UK organizations. Management Accounting Research, 18(4), 399-424.

Al-Sayed M. and Dugdale, D. 2016. Activity-based innovations in the UK manufacturing sector: Extent, adoption process patterns and contingency factors. The British Accounting Review, 48(1), 38-58.

Armstong, P. 2002. The costs of activity-based management. Accounting Organizations and Society, 27(1), 99-120.

Balakrishnan, R., Hansen, S. and Labro, E. 2011. Designing an Effective Cost System. In Ima and the Association of Accountants and Financial Professionals in Business, United States of America, Available at: https://pdfs.semanticscholar.org/a6f2/ ee8abc941e375 accbed190c04cc1da195164.pdf.

Ben-Arieh, D. and Qian, L. 2003. Activity-based cost management for design and development stage. International Journal of Production Economics, 83(2), 169-183.

Bhimani, A. and Bromwich, M. 1992. Advanced manufacturing technology and accounting: a renewed alliance", Advanced Manufacturing Engineering, 5(3), 199-207.

Biddle, G.C. and Steinberg, R. 1985. Common cost allocation in the firm. In Peyton Young (ed.), Cost Allocation: Methods, Principles, Applications, North-Holland, Available at: https://ssrn.com/abstract=1865023.

Brierley, J.A. 2008. Toward an understanding of the sophistication of product costing systems. Journal of Management Accounting Research, 20 1), 61-78.

Brierley, J.A., Cowton, C.J. and Drury, C. 2001. Research into product costing practice: An European perspective. The European Accounting Review, 10(2), 215-256.

Brierley, J.A. 2010. The Detetrminants of Overheas Assignment Sophistication in Product Costing Systems. The Journal of Corporate Accounting \& Finance, 21(4), 69-75.

Brimson, J.A. 1986. How advanced manufacturing technologies are reshaping cost management. Management Accounting, 67(9), 25-29.

Cardinaels, E. and Labro E. 2009. Time estimates as cost drivers. CIMA Research Executive Summaries Series, 5(1), 1-6.

Chen, FF. (1996. Activity-based approach to justification of advanced factory management systems. Industrial Management \& Data Systems, 96(2), 17-24.

Chenhall, R. 2003. Management control systems design within its organizational context: Findings from contigency-based research and direction for the future. Accounting Organizations and Society, 28(2), 127-168.

Cinquini L., Collini, P., Marelli, A. and Tenucci A. 2013. Change in the relavance of cost information and costing systems: Evidence from two Italian surveys. Journal of Management Governance, 19(3), 557-587.

Cohen, S. \& Kaymenaki, E. 2005. Anatomy of cost accounting systems in Greece. Accountant, May, 841-847.

Cooper, R. and Kaplan, R.S. 1988. How cost accounting distorts product costs. Strategic Finance, 69(10), 20-27.

Dimitras, A. and Ballas, A. 2009. Managerial Accounting for planning and control. Eds., Gutemberg, Athens.

Dimitriadi, Z. 2000. Methodology of Scientific Research. Interbooks, Athens.

Drury, C. 2000. Management and Cost accounting. $5^{\text {th }}$ ed. London: Thomson Learning.

Drury, C. and Tayles, M. 2005. Explicating the design of overhead absorption procedures in UK organizations. The British Accounting Review, 37(1), 47-84. 
Fisher, J. and Krumwiede, K. 2012. Product Costing Systems: Finding the Right Approach. Journal of Corporate Accounting \& Finance, 23(3), 43-51.

Fixson, S.K. 2004. Assesing product architecture costing: product life cycles, allocation rules and cost models. Proceedings of DECT2004-57458 (Design Engineering Technical Conferences and Computers and Information in Engineering Conference), American Society of Mechanical Engineers, Salt Lake City, Utah, 857-868.

Friedl, G., Küpper, H. U. and Pedell, B. 2005. Relevance added: Combining ABC with German cost accounting. Strategic Finance, 86(12), 56-61.

Fritzsch, R.B.1997. Activity-Based Costing and the Theory of Constraints: Using Time Horizons to Resolve Two Alternative Concepts of Product Costs. Journal of Applied Business Research, 14(1), 83-89.

Fullerton, R.R. and McWatters, C.S. 2004. An empirical examination of cost accounting practices used in advanced manufacturigt enviornments. Advances in Managment Accounting, 12(1), 85-113.

Garrison, R. \& Noreen, E. 2006. Managerial Accounting. Athens.

Gosselin, M. 1997. The effect of strategy and organizational structure on the adoption and implementation of activity-based costing. Accounting, Organizations and Society, 22(2), 105-122.

Grasso, L.P. 2005. Are ABC and RCA Accounitng Systems Compatible with Lean Management. Management Accounting Quarterly, 7(1), 12-27.

Gunasekaran, A., Williams, J.H. and McGaughey R. 2005. Perfomance mesurement and costing system in new enterprise. Technovation, 25(5), 523-533.

Gupta, M. 1993. Heterogeneity issues in aggregated costing systems. Journal of Management Accounting Research, 5, 180-212.

Heitger, D.L. 2007. Estimating activity costs: How provision of accurate historical activity data from a biased cost system can improve individuals' cost estimation accuracy. Behavioral Research in Accounting, 19, 133-159.

Hilton, R.W. 2002. Managerial Accounting, Creating Value in a Dynamic Business Enviornment, $5^{\text {th }}$ ed. NY: Mc Graw Hill.

Hoque, Z. and James, W. 2000. Linking the balance scorecard measures to size and market factors: Impact on organizational performance. Journal of Management Accounting Research, 12(1), 1-17.

Horngren, C.T., Bhimani, A., Datar, S.M. and Foster, G. 2005. Management and Cost Accounting. $3^{\text {rd }}$ ed. Prentice Hall.

Ismail, T.H. and Mahmoud, M.N. 2012. The Influence of Organizational and Environmental Factors on Cost Systems Design in Egypt. British Journal of Economics, Finance and Management Sciences, 4(2), 31-51.

Kaplan, R. and Cooper R. 1998. Cost and Effect: Using Integrated Cost Systems to Drive Profitability and Performance. Boston: Harvard Business School Press.

Karmarkar, U. and Pitbladdo, R. 1994. Product-line selection, production decisions and allocation of common fixed costs. International Journal of production economics, 34(1), 17-33.

Kaymenaki, E. 2008. An analytical investigation of the impact of cost accounting features on the quality of cost accounting and corporate performance.

Kee, R. 2008. The sufficiency of product and variable costs for production-related decisions when economies of scope are present. International Journal Production Economics, 114(2), 682-696.

Keisidou, E., Sarigiannidis, L., Maditinos, D. and Thalassinos, I.E. 2013. Customer 
satisfaction, loyalty and financial performance: A holistic approach of the Greek banking sector in Marketing Intelligence and Planning, 31(4), 259-288, Emerald Group Publishing Ltd., DOI: 10.1108/IJBM-11-2012-0114.

Kellermanns, F. and Islam, M. 2004. US and German activity-based costing. Benchmarking: An International Journal, 11(1), 31-51.

Krumwiede, K., Suessmair, A. and MacDonald, J. 2013. A Framework for Measuring the Complexity of Cost Systems. AAA Management Accounting Section (MAS) Meeting Paper.

Krumwiede, R.K. and Suessmair, A. 2006. Factors affecting the adopiton, infusion and perceived success of German cost accounting methods, AAA Management Accounting Section (MAS) Meeting Paper.

Lamminmaki, D. and Drury, C. 2001. A comparison of New Zealand and British productcosting practices. The International Journal of Accounting, 36(3), 329-347.

Lea, Bih-Ru and Fredendall, D.L. 2002. The impact of management accounting, product structure, product mix algorithm, and planning horizon on manufacturing performance. International journal of production economics, 79(3), 279-299.

Lere, J.C. 2001. Your product-costing system seems to be broken: Now What? Industrial Marketing Management, 30(7), 587-598.

Liapis, K., Thalassinos, I.E. 2013. A Comparative Analysis for the Accounting Reporting of "Employee Benefits" between IFRS and other Accounting Standards: A Case Study for the Biggest Listed Entities in Greece. International Journal of Economics and Business Administration, 1(1), 91-116.

Lowder, T. 2006. The legacy of activity based costing. Addressing the need for a hybrid methodology for costs allocation. Available at: http://ssrn.com/abstract=920957.

Lukka, K. and Granlund, M. 1996. Cost Accounting in Filand: current practice and trends of developmenet. European Accounting Review, 5(1), 1-28.

Major, M. and Hopper, T. 2005. Managers divided: Implementing ABC in a Portuguese telecomminications company. Management Accounting Research, 16(2), 205-229.

Oberholzer, M. and Ziemerink, J.E.E. 2004. Cost behavior classification and cost behaviour structures of manufacturing companies. Meditari Accountancy Research, 12(1), 179-207.

Professional Accountants in Business Committee (P.A.I.B.) 2009. Evaluating the Costing Journey: A Costing Levels Continuum Maturity Model. International Federation of Accountants (IFAC).

Rayburn, L.G. 1996. Cost Accounting, Using a cost management approach. $6^{\text {th }}$ ed. Irwin.

Reinstein, A. and Bayou, M. 1997. Product costing continuum for managerial decisions. Managerial Auditing Journal, 12(9), 490-497.

Saunders, M., Lewis, P., Thornhill, A. 2009. Research methods for business students. $5^{\text {th }}$ edit. Essex: Pearson Education Limited.

Schildbach, T. 1997. Cost Accounting in Germany. Management Accounting Research 8(3), 261-276.

Schoute, M. 2009. The relationship between cost system complexity, purpose of ues, and cost system effectivness. The British Accounting Review, 41(4), 208-226.

Shil, N.C., Hoque, M. and Akter, M. 2015. Influence of Decision-Making Goal and Accurate Product-Costing Goal on the Design of Sophisticated Costing Systems: Proposal of Multi-Goal Coordination Approach. In Moden and Minagawa (eds.), Lean Management of Global Supply Chain, World Scientific Publishing, Singapore.

Szendi, J.Z. and Elmore, R.C. 1993. Management accounting: Are new techniques making in-roads with practitioners? Journal of Accounting Education, 11(1), 61-76. 
Tatsiopoulos, I., Marmaras, N. and Chatzigiannakis, D. 2010. Industrial Management \& Costing, Papasotiriou, Athens.

Thalassinos, I.E. and Liapis, K. 2014. Segmental financial reporting and the internationalization of the banking sector. Chapter book in, Risk Management: Strategies for Economic Development and Challenges in the Financial System, (eds), D. Milos Sprcic, Nova Publishers, 221-255, ISBN: 978-163321539-9; 978-163321496-5.

Tsai, W.H. 1996. A technical note on using work sampling to estimate the effort on activities under activity-based costing. International Journal of production economics, 43(1), 11-16.

Tse, M.S. 2011. Antecedents and consequences of cost information usage in decision making. Advances in Management Accounting, 19, 205-223.

Udpa, S. 2001. Activity cost analysis: a tool to cost medical services and improve quality of care. Managed care quarterly, 9(3), 34-41.

Venieris, G. and Cohen, S. 2008. Flexibility in manufacturing and Activity Based Costing: Modelling the interrelationships. The Journal of Applied Business Research, 24(2), 8196.

Venieris, G. and Cohen, S. 2007. Managerial Accounting. Pela Ioannidou Publishing, A $\theta$ ńva. Wihinen, K. 2012. Exploring Cost System Design Principles: The Analysis of Costing System Sophistication in a Pricing Context. Ph.D Thesis, Tampere University of Technology, Finland, Available at: https://dspace.cc.tut.fi/dpub/handle/123456789/21279. 